\title{
Caraipa ANdina (CluSiaCEAe), A NEW SPECIES From THE VENEZUELAN ANDES, AND ITS BIOGEOGRAPHICAL IMPLICATIONS
}

\author{
Gerardo A. Aymard C. ${ }^{1}$ \& Lisa M. Campbell ${ }^{2}$
}

\begin{abstract}
(Caraipa andina (Clusiaceae), a new species from the Venezuelan Andes, and its biogeographical implications) Caraipa andina from La Fundación, in the western Andes of Venezuela (Táchira State) is described, illustrated, and its morphological relationship with an allied species is discussed. This new species is morphologically related to $C$. heterocarpa Ducke, but it differs by the leaf blade shape, size, and dense abaxial papillae; fewerflowered inflorescence; and shorter pedicel, flower buds, petals, and filaments. Phytogeographical information about the La Fundación area is presented. This species represents the first report of this genus in the Venezuelan Andes.
\end{abstract}

Key words: Amazonia, Estado Táchira, Guayana, Guttiferae, sandstone outcrops.

Resumo

(Caraipa andina (Clusiaceae), uma nova espécie para os Andes da Venezuela e suas implicações biogeográficas) Caraipa andina foi descoberta em La Fundación, nos Andes Ocidentais da Venezuela (Estado de Táchira) e é aqui descrita e ilustrada, discutindo-se suas afinidades morfológicas com as espécies próximas. Morfologicamente relacionada com C. heterocarpa Ducke, a nova espécie diferencia-se pelo tamanho, forma da lâmina foliar e face abaxial densamente papilosa; inflorescência paucifloras; pedicelos, botões florais, pétalas e filamentos mais curtos. Informações sobre a fitogeografia do local são apresentadas. Esta espécie representa o primeiro registro deste gênero nos Andes Venezuelanos.

Palavras-chave: Amazônia, Estado Táchira, Guayana, Guttiferae, afloramentos de arenito.

Caraipa Aublet comprises about 30 species of small to large trees or shrubs, distributed in tropical South America (Gustafsson et al. 2002; Stevens 2007). The genus has been variously treated as Bonnetiaceae, Theaceae, and is presently included in Clusiaceae (Kubitzki 2007). The genus is characterized by an indumentum of usually stellate hairs; alternate leaves with tertiary veins perpendicular to the secondary veins; stamens with free filaments and bearing an apical gland; and capsular fruits.

Species occur in moist forest formations (lowland, montane slopes, gallery, flooded, and Amazonian caatinga) and shrubby savannas, with the largest number of species in the Amazon Basin and on the Guiana Shield. However, a few taxa occur outside of this region, such as the two subspecies of $C$. densifolia Martius in southeastern and central Brazil. Three species $(C$. densifolia Martius subsp. densifolia, $C$. punctulata Ducke and $C$. richardiana Cambess.) are found in the wet and gallery forests in the Venezuelan Llanos (Aymard 2003; Aymard \& González 2006). Caraipa llanorum Cuatr. subsp. llanorum and $C$. savannarum Kub. form ecologically interesting communities of dense trees called saladillales. These communities are very common in the vast eolic, seasonally flooded savannas (the Llanos) that extend from northeastern Colombia through western Venezuela (Schargel \& Aymard 1992; Huber et al. 2006). The genus is rare in the Andes, and currently is known only by several collections of $C$. punctulata Ducke from Colombia (Antioquia and Norte de Santander departments), and reported herein for Venezuela. A revision of the genus was published by Kubitzki (1978; as Bonnetiaceae), who reconized 21 species and three morphological groups; however, these groups did not

Artigo recebido em 11/2007. Aceito para publicação em 04/2008.

${ }^{1}$ Corresponding author: UNELLEZ-Guanare, Programa de R. N. R., Herbario Universitario (PORT), Mesa de Cavacas, Estado Portuguesa, Venezuela 3350. gaymard@ cantv.net

${ }^{2}$ The New York Botanical Garden, Bronx, NY 10458-5126, U.S.A. 1campbell@nybg.org 
accommodate all of the species. Kubitzki (1978) pointed out two taxonomically useful leaf characters to separate the species: phyllotaxy spiral vs. distichous, and the cells of the abaxial surface bullate or clavate, with the cuticle minutely wrinkled and scaly vs. cells of the abaxial surface not protruding, and the cuticle mostly smooth. Since then, five new species have been described (Kubitzki 1987; Vásquez-Martínez, 1991) and others suggested (Kubitzki \& Holst 1998; see also Stevens 2007). Additionally, the genus has been treated for the Flora of the Venezuelan Guayana (Kubitzki \& Holst 1998), and two local florulas in the Amazonian region of Colombia and Peru (VásquezMartínez 1997; Rudas \& Prieto 2005).

This contribution increases to fifteen the number of Caraipa species known from Venezuela. This new species represents the first record of this genus in the Venezuelan Andes, and was discovered during herbarium work for a phytogeographic study being conducted in the area in which it was collected.

Caraipa andina Aymard \& L. M. Campb. sp. nov.

Fig. 1

Type: VENEZUELA. TÁCHIRA: Dtto. Uribante, empresa Las Cuevas, near La Fundación, 08 $50^{\circ} \mathrm{N}, 71^{\circ} 47^{\prime} \mathrm{W}$, ca. $900 \mathrm{~m}$, 7.VII.1983, H. van der Werff \& A. González 5013 (Holotype: PORT; Isotype: MO, n.v.; NY; VEN).

Species Caraipa heterocarpae Ducke proxima, sed differt: foliis oblongis, $6-9 \mathrm{~cm}$ longis, subtus dense papillatis, inflorescencia 12-16-flora, pedicellis 5-10 mm longis, gemmis floralibus 4-6 longis, sepalis ovatis, ca. $2 \mathrm{~mm}$ longis, intus adpress luteo-pubescentibus, petalis 6-8 longis, filamentis 5-6 longis, ovario dense luteoglandulosis trichomatibus obtecto.

Tree, $20 \mathrm{~m}$ tall. Young branches and branchlets smooth, glabrous. Leaves distichous, petiole 6-8 mm long, stout, glabrous; blades coriaceous, 6-9 cm long, 3-5 cm wide, base rounded, apex acute to rounded, margins slightly revolute, glabrous on both surfaces with sparse translucent dots, abaxial epidermal cells papillate, with microscopic epicuticular wax, secondary veins in $8-10$ pairs, impressed adaxially, prominent abaxially. Inflorescence axillary, lax panicles, 10-15 cm long, 12-16-flowered; the rachis and pedicels covered by simple and stellate trichomes; pedicels 5-10 mm long, bracts and bracteoles not seen. Flower buds globose, 4-6 cm long before anthesis; sepals ovate, ca. $2 \mathrm{~mm}$ long, ca. $2 \mathrm{~mm}$ wide, stellate pubescent and covered with translucent dots abaxially, adpressed yellow pubescent adaxially, margins ciliate; petals oblong, 6-8 $\mathrm{mm}$ long, 3-5 $\mathrm{mm}$ wide, puberulent abaxially, glabrous adaxially; stamens $80-100$, filaments 5-6 mm long, anthers ca. $0.5 \mathrm{~mm}$ long, oblong, introrse, connective distally widened and topped by a gland; ovary ca. $2 \mathrm{~mm}$ long, tomentose, trichomes yellow; style ca. $3 \mathrm{~mm}$ long, glabrous, stigma trilobed. Fruits not seen. Distribution and habitat: Caraipa andina appears to be restricted to the moist montane forests near La Fundación, Táchira state, Venezuela.

Phenology: Collected with flowers in July.

The ranked phyllotaxis, with leaves glabrous on both surfaces, cells of their lower surface not protruding, and with a smooth cuticle, and lax panicles more $4 \mathrm{~cm}$ long, relate this new species morphologically to Caraipa heterocarpa, a species known from a few specimens, with restricted distribution in low elevation flooded forests in the Amazon basin of Brazil and Venezuela (Kubitzki 1978; Kubitzki \& Holst 1998). However, C. andina differs from that species by its leaf blades oblong, 6-9 cm long, densely papillate on the abaxial surface ( $v s$. leaf blades lanceolateovate or lanceolate, 10-17 cm long, not papillate on the abaxial surface), inflorescence with 1216 flowers, pedicels 5-10 $\mathrm{mm}$ long ( $v s$. inflorescence with 20-40 flowers, pedicels 12 $16 \mathrm{~mm}$ long), flower buds 4-6 cm long; sepals ovate, ca. $2 \mathrm{~mm}$ long, adpressed yellow pubescent adaxially, petals $6-8 \mathrm{~mm}$ long, and filaments 5-6 mm long ( $v s$. flower buds 7-8 cm long; sepals obtuse, 3-4 mm long, slightly strigose adaxially, petals ca. $10 \mathrm{~mm}$ long, and filaments $10-12 \mathrm{~mm}$ long). 


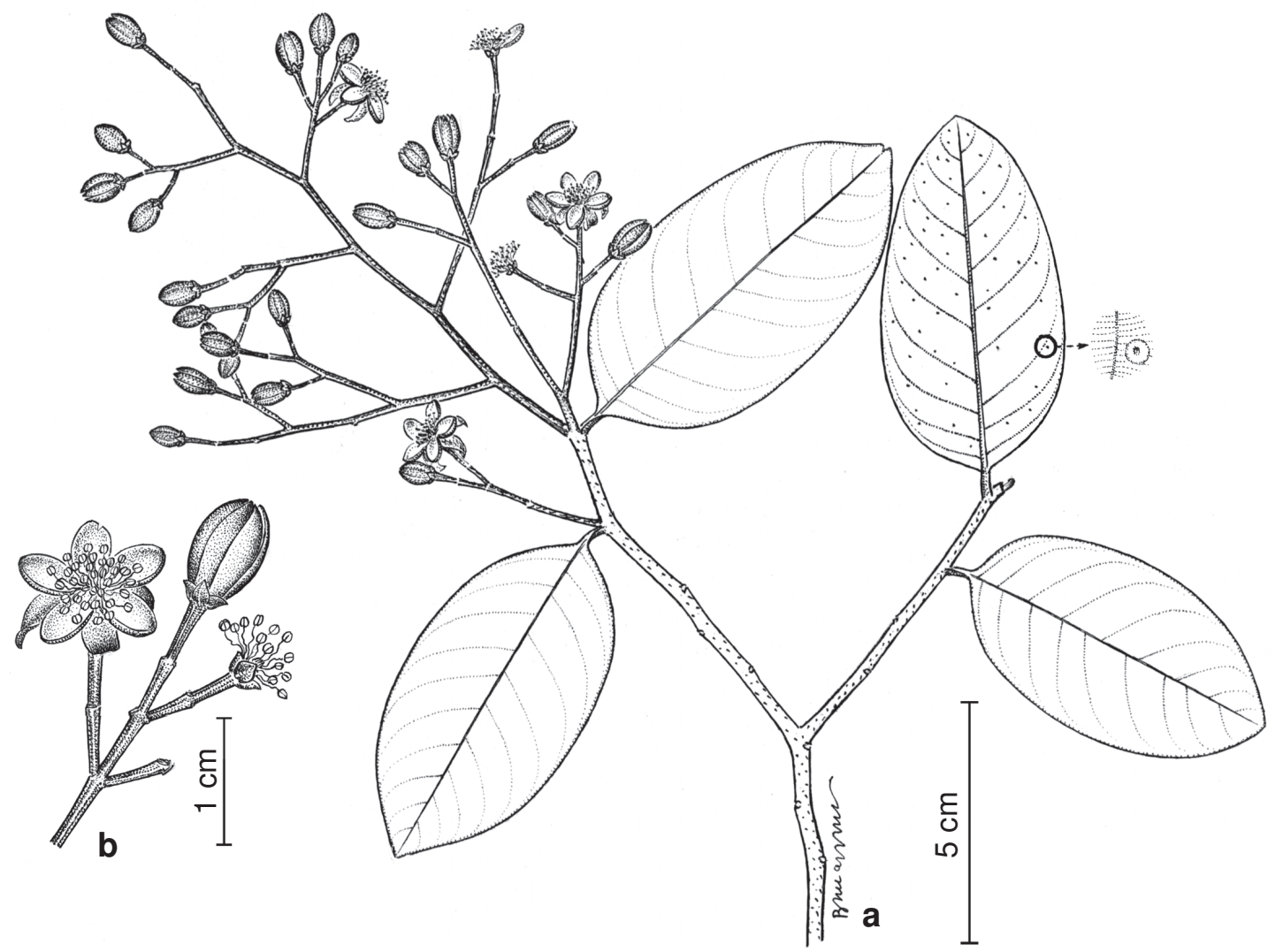

Figure 1 - Caraipa andina - a. branch showing the inflorescence and flowers; b. detail of an inflorescence branch. (van der Werff 5013).

Phytogeography: Species of Caraipa are distributed almost exclusively in the Guayana region and Amazon Basin, and are rarely encountered in the tropical Andes. The first report of the genus in this region was $C$. colombiana Ewan, a species described from a collection from forests on the slopes of the Cordillera Central in Colombia (Ewan 1951). Kubitzki (1978) treated this species as a synonym of $C$. punctulata Ducke, a mostly lowland wet forest species, that he considered to also be distributed on mountain slopes in Venezuela and Colombia; notably, he did not mention that this collection ( $J$. Cuatrecasas $13335, \mathrm{~F}, \mathrm{US}$ ) would have represented the only known occurrence of Caraipa in the Andes. Intensive botanical exploration in the Colombian Andes during the last twenty-five years revealed that the distribution of Caraipa extends to the Central Cordillera in Antioquia department.
The only known locality of Caraipa andina, La Fundación, is located in the western portion of the Cordillera Mérida, on sandstone outcrops belonging to the Formación Aguardiente (Notestein et al. 1944; Salvador 1961a, b). The vegetation of this area is relatively well known because of the extensive collections made by $\mathrm{R}$. Liesner, J. A. Steyermark and H. van der Werff. Liesner (pers. comm.) observed that the floristic composition of the vegetation associated with these sandstone outcrops includes several species that are known from the Guiana Shield, and the Amazon Basin floras, such as Philodendron atabapoense G. S. Bunting (Araceae), Bonnetia paniculata Spruce ex Benth. (Bonnetiaceae), Vriesia duidae (L. B. Sm.) Gouda (Bromeliaceae), Licania latifolia Benth. (Chrysobalanacae), Elaphoglossum horridulum (Kaulf.) J. Sm., E. raywaense (Jenman) Alston (Dryopteridaceae), and Pleurothallis erebatensis Carnevali \& Romero (Orchidaceae). Additionally, the flora 
includes many endemic species (e.g., Licania tachirensis Prance (Chrysobalanaceae), Piper fundacionense Steyerm. (Piperaceae), Clidemia steyermarkii Wurdack, Miconia liesneri Wurdack (Melastomataceae), and Securidaca fundacionensis Aymard \& L. M. Campb. (Polygalaceae; see Aymard \& Campbell 2007).

The entire Tertiary is characterized by tectonic events and changes in climate and sealevel (Hooghiemstra \& van der Hammen 2004). These continuously affected the present-day Venezuelan Andes, which then were a lowland contiguous with the Guayana and Amazonia regions (van der Hammen \& Hooghiemstra 2000; Hooghiemstra et al. 2006). The Western Cordillera is the most recently uprised (Kroonenberg et al. 1990) of the northern Andes complex, and paleobotanical and geomorphological data indicate that its final uplift was completed around 4-3 MYA (GregoryWodzicki 2000; H. Hooghiesmstra, pers. com.). The progressive physical separation of the Andes from the ancient Guayana region resulted in the present Andean flora: a mosaic of endemics, and elements from the Guayana, Amazonia, south-temperate, and northtemperate floras (van der Hammen \& Cleef 1984; van der Hammen \& Hoogghiemstra 2000; Hooghiemtra et al. 2006).

No descriptive analysis of vegetation types from the sandstone rocks and sand substrates of the Venezuelan Andes has been undertaken thus far. Furthermore, few studies have examined whether taxa occurring in the Andes considered to be Amazonia-Guayana relicts do indeed have a lowland origin, and whether present disjunctions are a result of vicariance or dispersal. Studies on two families with high species diversity in both the Guayana region and the Andes (Bromeliaceae [Givnish et al. 2004] and Gentianaceae:Helieae [Gould \& Struwe 2004]) suggest different histories leading to the modern distribution: evolution of the group in the lowlands and dispersal to the Andes (Givnish et al. 2004), or Andean origins with subsequent radiation (Gould \& Struwe 2004). Lacking rigorous hypotheses of relationship, it would be premature to speculate if either of these scenerios applies to Caraipa. The description of this interesting new species re-enforces Kubitzki's (1978) observation that the genus is still in need of study.

A broader biogeographic question remains regarding the affinities of floras occurring on vicariant sandstone habitats. In future research we will make comparative surveys of the floras occupying habitats on sandstone from both the Guayana and Amazon regions (G. A. Aymard C., L. M. Campbell, and G. RomeroGonzález, in prep.).

\section{ACKNOWLEDGMENTS}

The authors are grateful to Richard Schargel (UNELLEZ-Guanare), Franco Urbani (UCV-Caracas), Antoine Cleef (IBEDThe Netherlands), Henry Hooghiemstra (IBEDThe Netherlands), and Gustavo Romero-G. (AMES) for comments and suggestions on the manuscript. We thank Bruno Manara (VEN) for preparing the illustration and for his expertise in preparing the Latin diagnosis, $\mathrm{R}$. Liesner (MO) for sharing his knowledge of the flora near La Fundación, and the staff of Institute for Biodiversity and Ecosystem DynamicsUniversity van Amsterdam, Missouri Botanical Garden, and New York Botanical Garden for making their facilities available for this research.

\section{REFERENCES}

Aymard, G. \& Campbell, L. M. 2007. A new species of Securidaca (Polygalaceae) from sandstone outcrops in the Venezuelan Andes. Brittonia. 59: 328-333. 2003. Bosques de los Llanos de Venezuela: consideraciones generales sobre su estructura y composición florística. In: Hétier, J. M. \& López F, R. (eds.) Tierras Llaneras de Venezuela, IRD \& CIDIAT (Universidad de Los Andes), Mérida, Venezuela. Pp. 19-48.

\& González, V. 2006. Consideraciones generales sobre la composición florística y diversidad de los bosques de los Llanos de Venezuela. In: Duno de Stefano, R.; Aymard, G. \& Huber, O. (eds.). Catálogo 
ilustrado y anotado de las plantas vasculares de los Llanos de Venezuela. FUDENA, Fundación Polar, \& FIBV, Caracas. Pp. 59-72.

Ewan. J. 1951. Taxonomic notes on various species of Musaceae, Marcgraviaceae, Guttiferae, and Solanaceae of Colombia. Natural History Miscellanea 88: 1-9.

Givnish, T. S.; Millam, K. C.; Evans, T. M.; Hall, J. C.; Pires, J. C.; Berry, P. E. \& Systsma, J. K. 2004. Ancient vicariance or recent long-distance dispersal? Inferences about phylogeny and South American-African disjunctions in Rapateaceae and Bromeliaceae based on $n d h \mathrm{~F}$ sequence data. International Journal of Plant Science 165: 834-854.

Gould, K. \& Struwe, L. 2004. Phylogeny and evolution of Symbolanthus and Wurdackanthus (Gentianaceae-Helieae) in the Guayana highlands and Andes, based on ribosomal 5S-nts sequences. Annals of the Missouri Botanical Garden 91: 438-446.

Gregory-Wodzicki, K. M. 2000. Uplift history of the central and northern Andes: A review. Geographic Society of America Bulletin 112: 1091-1105.

Gustafsson, M. H. G.; Bittrich, V. \& Stevens, P. F. 2002. Phylogeny of Clusiaceae based on $\mathrm{rbcL}$ sequences. International Journal of Plant Sciences 163: 1045-1054.

Hooghiemstra, H. \& van der Hammen, T. 2004. Quaternary ice-age dynamics in the Colombian Andes: developing and understanding of our legacy. Philosophical Transactions of the Royal Society London. Series B, 359: 173-181.

\& Cleef, A. M. 2006. The paleobotanical record of Colombia; implications for biogeography and biodiversity. Annals of the Missouri Botanical Garden. 93: 297-325.

Huber, O.; Duno de Stefano, R.; Aymard, G.; \& Ricarda Riina, R. 2006. Flora and vegetation of the Venezuelan Llanos: A review. In: Pennington, R. T.; Lewis, G. P. \& Ratter, J. A. (eds.). Neotropical savannas and dry forests: plant diversity, biogeography and conservation. CRC Press, Boca Raton, Florida. Pp. 95-120.

Kroonenberg, S. B.; Bakker, J. G. M. \& van der Wiel, A. M. 1990. Late Cenozoic uplift and paleogeography of the Colombian Andes: constraints on the development of high-Andean biota. Geologie en Mijnbouw 69: 279-290.

Kubitzki, K. 1978. Caraipa and Mahurea (Bonnetiaceae). In: Maguire, B. (ed.). The botany of the Guayana Highland-X. Memoirs of the New York Botanical Garden 29: 82-138. 1987. Three new species of Caraipa (Guttiferae). Acta Amazonica 16-17: 157-160. (ed.). 2007. The families and genera of vascular plants. Vol. 9. Springer, New York. \& Holst, B. 1998. Caraipa (Clusiaceae). In: Berry, P. E.; Holst, B. K. \& Yatskievych, K. (eds.). Flora of Venezuelan Guayana. Vol. 4. Missouri Botanical Garden, St. Louis. Pp. 252-258.

Notestein, F. B.; Hubman C. W. \& Bowler, J. W. 1944. Geology of the Barco Concession, Republic of Colombia, South America. Geological Society of America Bulletin 55: 1165-1216.

Rudas, A. \& Prieto, A. 2005. Flórula del Parque Nacional Natural Amacayacu, Amazonas, Colombia. Monographs in Systematic Botany from the Missouri Botanical. Garden. 99: 1-655.

Salvador, A. 1961a. Nomenclature of the Las Piedras and related formations in eastern Venezuela. Boletin Informativo de la Asociacion Venezolana de Geologia, Minas y Petroleo 4(10): 297-327. 1961b. Guidebook to the geology of northeastern Trujillo. Sociedad Geologica Venezolana, Occidente $\mathrm{N}^{\circ} 3$.

Schargel, R. \& Aymard, G. 1992. Observaciones en suelos y vegetación en la planicie eólicalimosa del Alto Río Cinaruco. Dtto. Muñoz, Estado Apure, Venezuela. Biollania9: 119-147.

Stevens, P. F. 2007. Clusiaceae-Guttiferae. In: Kubitzki, K. (ed.). The families and genera of vascular plants. Vol. 9. Springer, New York. Pp. 48-66. 
van der Hammen, T. \& Cleef. A. 1984. Datos para la historia de la flora Andina. Revista Chilena de Historia Natural 56: 97-107. \& Hoogghiemstra, H. 2000. Neogene and quaternary history of vegetation, climate, and plant diversity in Amazonia. Quaternary Science Reviews 19: 725-742.
Vásquez-Mártinez, R. 1991. Caraipa (Guttiferae) del Perú. Annals of the Missouri Botanical Garden 78: 1002-1008.

1997. Flórula de las reservas biológicas de Iquitos, Perú. Monographs in Systematic Botany from the Missouri Botanical Garden 63: 1-1046. 